\title{
Ayçiçeği (Helianthus annuus L.)'nde Azot ve Kükürt Gübrelemesinin Verim ve Kaliteye Etkileri
}

\author{
Sabri ERBAŞ ${ }^{* 1}\left(\mathbb{D}\right.$, Ali ŞENATEŞ$^{2}$ (1) \\ 1,2Isparta Uygulamalı Bilimler Üniversitesi, Ziraat Fakültesi, Tarla Bitkileri Bölümü, 32260, Isparta, Türkiye
}

(Alınış / Received: 22.01.2020, Kabul / Accepted: 17.03.2020, Online Yayınlanma / Published Online: 20.04.2020)

Anahtar Kelimeler
Ayçiçeği,
Helianthus annuus,
Azot,
Kükürt,
Verim ve kalite

Anahtar Kelimeler

Helianthus annuus,

Kükürt,

Verim ve kalite
Özet: Bu araştırmada ayçiçeğinde azot $(0,5,10,15 \mathrm{~kg} \mathrm{~N} / \mathrm{da})$ ve kükürt $(0,5,10,15$ $\mathrm{kg} \mathrm{S/da)} \mathrm{uygulamalarının} \mathrm{verim} \mathrm{ve} \mathrm{kalite} \mathrm{özellikleri} \mathrm{üzerine} \mathrm{etkilerinin}$ belirlenmesi amaçlanmıştır. Isparta Uygulamalı Bilimler Üniversitesi Ziraat Fakültesi Tarla Bitkileri Bölümü'nde 2014 ve 2015 yıllarında yürütülmüştür. Deneme bölünmüş parseller deneme deseninde kurulmuş, ana parsellere azot ve alt parsellere de kükürt dozları uygulanmıştır. Çalışmada bütün özelliklerin yıllar arasındaki farklılıkları; kabuk oranı ve yağ oranı hariç diğer özelliklerin N dozları arasındaki farklılıklar; yağ oranı hariç diğer özelliklerin S dozları arasındaki farklılıkları \%1 düzeyinde önemli bulunmuştur. Elde dilen sonuçlara göre, tohum verimi 2014 yllında $235.4-348.6 \mathrm{~kg} / \mathrm{da}\left(\mathrm{N}_{0} \mathrm{~S}_{0}-\mathrm{N}_{5} \mathrm{~S}_{5}\right)$ ve 2015 yllında ise 174.4-327.4 $\mathrm{kg} / \mathrm{da}\left(\mathrm{N}_{0} \mathrm{~S}_{0}-\mathrm{N}_{10} \mathrm{~S}_{5}\right)$ arasında değişmiştir. Azot dozu ortalamalarına göre kontrol parsellerinde $231.9 \mathrm{~kg} / \mathrm{da}$ olan tohum verimi $10 \mathrm{~kg} /$ da'a kadar \%31.3 oranında artış göstermiș ve $304.4 \mathrm{~kg} /$ da'a ulaşmıștır. Kükürt dozu ortalamalarına göre en yüksek tohum verimi $5 \mathrm{~kg} /$ da uygulamasından (302.8 kg/da) ve en düşük kontrol parsellerinden (248.4 kg/da) elde edilmiştir. Tohumların yağ içeriği kontrole göre yüksek $\mathrm{N}$ ve $\mathrm{S}$ dozu uygulamasında sırasıyla \%2.1 ve \%5.0 oranında artmıştır. Sonuç olarak; Isparta koşullarında yağlık ayçiçeği yetiştiriciliğinde daha yüksek tane verimi ve kalitesi için $10 \mathrm{~kg} \mathrm{~N} /$ da azot ile $5 \mathrm{~kg} \mathrm{~S} /$ da kükürt kullanılmalıdır.

\section{Effects of Nitrogen and Sulfur Fertilization on Yield and Quality in Sunflower (Helianthus annuus L.)}

Keywords

Sunflower,

Helianthus annuus,

Nitrogen,

Sulphur,

Yield and quality

\begin{abstract}
This study was carried out to determine the effects of nitrogen $(0,5,10$, $15 \mathrm{~kg} \mathrm{~N} / \mathrm{da})$ and sulfur $(0,5,10,15 \mathrm{~kg} \mathrm{~S} / \mathrm{da})$ applications on yield and quality characteristics of sunflower in Isparta University of Applied Sciences, Faculty of Agriculture, Department of Field Crops in 2014 and 2015 years. The experiment design was in split plots of randomized complete blocks (Nitrogen doses were placed in the main plots) with three replications. The differences of all features between years in the study; differences between $\mathrm{N}$ doses of other properties except hull and oil content; differences between $\mathrm{S}$ doses of other properties except fat ratio were found to be significant at $1 \%$ level. According to our results, seed yield varied between $235.4-348.6 \mathrm{~kg} / \mathrm{da}\left(\mathrm{N}_{0} \mathrm{~S}_{0}-\mathrm{N}_{5} \mathrm{~S}_{5}\right)$ in 2014 and 174.4-327.4 $\mathrm{kg} / \mathrm{da}\left(\mathrm{N}_{0} \mathrm{~S}_{0}-\mathrm{N}_{10} \mathrm{~S}_{5}\right)$ in 2015 . Seed yield, which was $231.9 \mathrm{~kg} / \mathrm{da}$ in control plots, increased by $31.3 \%$ up to $10 \mathrm{~kg} / \mathrm{da}$ and reached $304.4 \mathrm{~kg} / \mathrm{da}$ according to the average of $\mathrm{N}$ dosage. According to the average of $\mathrm{S}$ dosage, the highest seed yield was obtained from $5 \mathrm{~kg} / \mathrm{da}(302.8 \mathrm{~kg} / \mathrm{da})$ and the lowest control plots $(248.4$ $\mathrm{kg} / \mathrm{da}$ ). The oil content increased by $2.1 \%$ and $5.0 \%$, respectively, in the application of high $\mathrm{N}$ and $\mathrm{S}$ doses compared to the control. As a result; in Isparta conditions, it can be recommended to use $10 \mathrm{~kg} \mathrm{~N} /$ da nitrogen and $5 \mathrm{~kg} \mathrm{~S} / \mathrm{da}$ sulfur in order to obtain higher yield and quality in oilseed sunflower cultivation.
\end{abstract}




\section{Giriş}

Dünyada 2017 yılında 26.5 milyon ha alanda 47.9 milyon ton ayçiçeği tohumu üretilmiştir. Ayçiçeği Rusya, Ukrayna, Güney ve Doğu Avrupa ülkeleri başta olmak üzere, birçok ülkenin en önemli bitkisel yağ kaynağıdır. Türkiye'de ise 2017 yılında 779 bin ha alandan 1.96 milyon ton tohum üretilmiştir [1]. Türkiye yağlı tohumlar ve bitkisel yağlar ticaretinde uzun yıllardır net ithalatçı (\%70) ülkeler arasında yer almaktadır. Çoğu tarımsal üründe yeterli üretim olmasına karşın, özellikle yağlı tohumlar ve bitkisel yağlar üretiminde artan nüfus yoğunluğu ve yağların kullanım olanaklarının genişlemesi ile birlikte diş ticaret açığı gittikçe büyümekte olup, petrol ve ürünlerinden sonra en büyük ikinci ithalat kalemi durumundadır. Türkiye'de 2018 yllında 3.7 milyon ton yağlı tohum (1.6 milyar \$), 1.3 milyon ton ham yağ (1.1 milyar \$), 3.5 milyon ton küspe (837 milyon \$) olmak üzere 3.5 milyar \$ değerinde toplam 8.5 milyon ton bitkisel yağ, yağlı tohum ve küspe ithal edilmiştir [2]. Türkiye'de yağ bitkileri ekim alanlarının $\% 75$ 'ten fazlasını ve bitkisel yağ üretiminin \%50'ye yakınını ayçiçeği (Helianthus annuus) karşılamaktadır. Yağlık ayçiçeği üretiminin yaklaşı \% \%75'i başta Tekirdağ, Edirne ve Kırklareli olmak üzere Trakya-Marmara Bölgesi'nde yapılmaktadır [1]. Ayçiçeğinin bitkisel yağ üretimine olan mevcut katkısının daha da artması için ekim alanlarının diğer bölgelerde de yaygınlaştırılması gerekmektedir. Türkiye'de yağlık ayçiçeği tarımının yaygınlaşabileceği bölgeler gerçekte halen yoğun şekilde serin iklim tahılları üretiminin yapıldığı kuru tarım alanlarıdır [3].

Tarımsal üretimde yüksek verimlilik için sertifikalı ve hibrit tohumluk kullanımının yanı sıra optimum gübre ve ilaç uygulamalarının yapılması gereklidir [4]. Zira üretimde büyümeyi sınırlayan temel sorunların yaklaşı \%60'ını mineral besin eksikliğinden kaynaklandığı rapor edilmektedir. Standart bir ayçiçeği üretiminde vejetatif gelişme döneminde $160 \mathrm{~kg} / \mathrm{da}$, generatif dönemde ise 900 $\mathrm{kg} / \mathrm{da}$ civarında kuru madde üretilmektedir [5]. Bu nedenle toprakta yeterli miktarda bitki besin elementlerine gereksinim duyulmaktadır. Ayçiçeği üretiminde gübrelerin çok maliyetli ve gelir marjlarının çok az olduğu göz önüne alındığında, atılan gübre miktarlarının ve etkileşimlerinin bilinmesi önem arz etmektedir. Ayçiçeğin üretimi için gereken bitki besin maddeleri arasında en önemlileri azotlu ve kükürtlü gübrelerdir. Azot erken büyüme döneminde, karbonhidratları daha iyi asimilasyonuna ve protein sentezine yardımcı olur. Ayrıca proteini artırır ve yağ konsantrasyonunu azaltarak tohum kalitesini de etkilemektedir [6]. Diğer taraftan kükürt protein sentezinde sistin, metionin ve sistein gibi amino asitlerin bileşenlerinin oluşumunda rol oynar [7] ve özellikle yağlı tohumlarda tohum ve yağ verimi ile yağ kalitesini artırıcı yönde olumlu etki yapmaktadır [8]. Bu nedenle yağlı tohumlu bitkiler diğer bitkilere göre daha fazla kükürt istemektedir. Kükürt noksanlığında ayçiçeğinin gelişiminin yavaşladığ veriminin azaldığı rapor edilmektedir [9]. Kükürt uygulaması ile ayçiçeğinde kuru madde, tabla çapı, tablada tohum ağırlığı ve sayısl, 1000 tohum ağırlığı ve tohum verimi ve biyolojik verimin arttı̆ edilmiştir [10]. Aynı zamanda kükürt klorofil ve vitamin (B, biyotin ve tiamin) sentezinde rol oynar ve özellikle protolitik enzimleri etkileyen büyüme ve metabolizması ile ilişkilidir [11]. Tarımsal verimlilikte önemli bir girdi olan gübrelerin tüketimi giderek artmaktadır. Fakat bu artış ile bazen beklenen seviyede üretim artışına yansımamaktadır. Bilinçsiz gübreleme ile toprağın verimlilik dengesi bozulmakta ve bu topraklarda yetiştirilen bitkilerden elde edilen ürünün kalitesi de azalmaktadır. Yürütülen bu araştırmada; Isparta koşullarında ayçiçeğinde farklı azot $(0,5,10,15 \mathrm{~kg} \mathrm{~N} / \mathrm{da})$ ve kükürt dozlarının $(0,5,10,15 \mathrm{~kg} \mathrm{~S} / \mathrm{da})$ yağlık ayçiçeğinde verim ve kalite özelliklerinin belirlenmesi amaçlanmıştır.

\section{Materyal ve Metot}

$\mathrm{Bu}$ çalışma Isparta Uygulamalı Bilimler Üniversitesi Ziraat Fakültesi Tarla Bitkileri Bölümünde (37045' K ve 30³3' D, $997 \mathrm{~m}) 2014$ ve 2015 yllarinda yürütülmüştür. Düet CL ayçiçeği çeşidi materyal olarak kullanılmıştır. Bu çeşit çiçeklenme süresi 6164 gün olan erkenci, mildiyonun (Köse) PL6 ırklarına yüksek derecede toleransll, yüksek yağ oranına sahip, tabla yapısı eğik ve dış bükey, stres koşullarına toleranslı, toprak seçiciliği olmayan ve alternaria, pas, septoria gibi mantari hastalıklarına karşı yüksek toleranslı bir çeșittir. Tarla denemelerinin kurulduğu yıllara ilişkin iklim verilerine göre, vejetasyon döneminde (Nisan-Ağustos) genel olarak ayçiçeği bitkisinin normal büyüme ve gelişmesini olumsuz yönde etkileyecek sıcaklıklar yaşanmamıştır. NisanHaziran ayları arasında bitkilerinin su ihtiyacı yağışlarla sağlanmıștır, ancak 2014 yılında bu dönemde 194.6 mm yağıș olurken, 2015 yilında 185.8 mm yağış düşmüştür (Tablo 1). Araştırma alanının toprak özellikleri Rowell [12]'e göre belirlenmiştir. Toprak killi-tınlı tekstürde olup, pH'sı 7.5, tuz oranı $\% 0.38$, organik madde içeriği \%1.1 (Walkley-Black), kireç içeriği \%7.20 (Schiebler kalsimetresi), alınabilir fosfor $3.9 \mathrm{mg} / \mathrm{kg}$ ve alınabilir potasyum içeriği 119.0 $\mathrm{mg} / \mathrm{kg}\left(1 \mathrm{~N} \mathrm{NH} \mathrm{NH}_{4} \mathrm{OAc}\right.$ )'dır. Bu yönüyle deneme alanı toprağı her ne kadar alkali, ağır yapılı ve organik maddesi düşük de olsa ayçiçeği tarımı için uygundur.

Deneme tesadüf bloklarında bölünmüş parseller deneme desenine göre 3 tekerrürlü olarak kurulmuş ve tohumlar ekimleri 10.04.2014 ve 08.04.2015 tarihlerinde $70 \times 25 \mathrm{~cm}$ ekim normunda $5 \mathrm{~m}$ uzunluğunda 5 sıra olacak şekilde yapılmıștır. Bir parselin alanı $17.5 \mathrm{~m}^{2}(5 \mathrm{~m} \times 3.5 \mathrm{~m})$ 'dir. Yabancı ot mücadelesi el çapası ile yapılmıştır. Her iki deneme yllında çiçeklenme öncesi dönemde (Temmuz) 
Tablo 1. Isparta ilinin 2014 ve 2015 yıllarına ait aylık ortalama yağıș, sıcaklık ve hava bağıl nem değerleri [13]

\begin{tabular}{lccccccccc}
\hline \multirow{2}{*}{ Aylar } & \multicolumn{3}{c}{ Yağış, $\left(\mathbf{L} / \mathbf{m}^{2}\right)$} & \multicolumn{4}{c}{ Sicaklı (oC) } & \multicolumn{3}{c}{ Bağll nem (\%) } \\
\cline { 2 - 10 } & $\mathbf{1 9 5 0 - 2 0 1 5}$ & $\mathbf{2 0 1 4}$ & $\mathbf{2 0 1 5}$ & $\mathbf{1 9 5 0 - 2 0 1 5}$ & $\mathbf{2 0 1 4}$ & $\mathbf{2 0 1 5}$ & $\mathbf{1 9 5 0 - 2 0 1 5}$ & $\mathbf{2 0 1 4}$ & $\mathbf{2 0 1 5}$ \\
\hline Ocak & 73.6 & 61.3 & 125.9 & 1.9 & 3.7 & 1.9 & 73.2 & 76.7 & 73.4 \\
Şubat & 64.0 & 23.4 & 57.7 & 2.9 & 5.2 & 3.3 & 70.2 & 60.8 & 68.4 \\
Mart & 55.3 & 78.6 & 111.6 & 6.2 & 7.3 & 6.7 & 65.3 & 63.3 & 64.8 \\
Nisan & 55.3 & 44.8 & 26.1 & 10.8 & 11.7 & 9.0 & 61.0 & 59.5 & 58.2 \\
Mayıs & 52.3 & 107.0 & 67.5 & 15.6 & 15.1 & 16.6 & 57.4 & 60.3 & 51.8 \\
Haziran & 30.6 & 42.8 & 92.2 & 20.2 & 20.0 & 18.3 & 51.2 & 49.8 & 63.5 \\
Temmuz & 14.6 & 0.8 & 3.0 & 23.7 & 24.5 & 24.2 & 45.3 & 43.5 & 43.9 \\
Ağustos & 11.7 & 10.2 & 43.4 & 23.2 & 24.9 & 23.8 & 46.4 & 44.2 & 51.0 \\
\hline
\end{tabular}

yağışın çok az olmasından dolayı 15 gün arayla 2 defa 2 'şer saat damla sulama yapılmıştır. Ekimle birlikte 8 $\mathrm{kg} \mathrm{P}_{2} \mathrm{O}_{5} / \mathrm{da}$ olacak şekilde triple süper fosfat (TSP) gübresi (18:46:0) atılmıştır. Ana parsellere azot dozları ( $\left.\mathrm{N}_{0}: 0, \mathrm{~N}_{5}: 5, \mathrm{~N}_{10}: 10, \mathrm{~N}_{15}: 15 \mathrm{~kg} / \mathrm{da}\right)$ ve alt parsellere ise kükürt dozları ( $\mathrm{S}_{0}: 0, \mathrm{~S}_{5}: 5, \mathrm{~S}_{10}: 10, \mathrm{~S}_{15}$ : $15 \mathrm{~kg} / \mathrm{da}$ ) uygulanmıştır. Azot kaynağı olarak amonyum nitrat gübresinin (\%33) yarısı ekimle, kalan yarısı da sapa kalkma döneminde uygulanmıştır. Kükürt kaynağl olarak ise elementel kükürt (\%98) ekimle birlikte uygulanmıştır. Çiçeklenme ve döllenme tamamlandıktan sonra kuş zararının önüne geçilmesi için parsellerdeki bitkilerin tablaları kese kâğıdı ile izole edilmiştir.

Olgunlaşma ile birlikte parsellerden tesadüfen seçilen 10 bitkide agronomik [çiçeklenme tarihi (gün), bitki boyu $(\mathrm{cm})$, tabla çapı $(\mathrm{cm}), 1.000$ tane ağırlığı $(\mathrm{g})$ ve tohum verimi $(\mathrm{kg} / \mathrm{da})]$ ve kalite [kabuk oranı (\%), yağ oranı (\%), yağ verimi $(\mathrm{kg} / \mathrm{da})$ ve yağ asitleri kompozisyonu (\%)] özellikleri incelenmiştir. Tohumların yağ analizleri Nükleer Manyetik Rezonans (NMR, Brüker mqone) cihazında \% olarak okutularak saptanmıştır. Tohumlar $70{ }^{\circ} \mathrm{C}$ ayarlı etüvde 48 saat bekletilerek nemi uçurulup 2'şer g tartılmış ve NMR cihazında her parselde 3 okuma yapılarak \% yağ oranı ortalaması hesaplanmıştır. Yağ asitleri kompozisyonu ise alev iyonlaşma detektöre (FID) sahip gaz kromotografisi (Shimadzu GC-2025) cihazında yapılmıştır.

2 g öğütülmüş tohum $n$-hekzan ile soğuk ekstraksiyona tutulmuş ve solvent karışımı uçurulduktan sonra elde edilen ham yağ AOAC [14] tarafından önerilen yöntemle \%0.5'lik Sodyum Metilat (NaoMe) ile metil esterlerine (FAME) dönüştürmüştür. Yağ asitlerine ilişkin kromatogramlar elde edilerek palmitik ( $\left.\mathrm{C}_{16: 0}\right)$, stearik ( $\left.\mathrm{C}_{18: 0}\right)$, oleik $\left(\mathrm{C}_{18: 1}\right)$ ve linoleik $\left(\mathrm{C}_{18: 2}\right)$ asit oranları belirlenmiştir. GC cihazının çalışma koşulları şu şekildedir; Kolon Teknokroma TR-CN100 (100 m × $0.25 \mathrm{~mm}, 0.20 \mu \mathrm{m}$ ), enjektör sıcaklığı $250^{\circ} \mathrm{C}$, detektör sıcaklığı $250{ }^{\circ} \mathrm{C}$, akış hızı (psi) 10 , taşıyıcı gaz N (40 $\mathrm{ml} / \mathrm{dk}$ ), enjektör kapasitesi $1.0 \mu$ l'dir. Fırın sıcaklığ $140{ }^{\circ} \mathrm{C}^{\prime}$ de 10 dakika bekledikten sonra $240{ }^{\circ} \mathrm{C}$ 'ye dakikada $3^{\circ} \mathrm{C}^{\prime}$ lik artışla ulaşıyor ve bu sıcaklıkta 10 dakika bekliyor. Elde edilen kromotogramlardaki pikler ticari standart yağ asidi metil ester karışımına
(Sigma, Supelco® 37 Component FAME Mix) göre isimlendirilmiştir. Elde edilen veriler tesadüf bloklarında bölünmüş parseller deneme desenine göre SAS [15] istatistik paket programında analiz edilmiş ve uygulamaların karşılaştırılmasında Duncan çoklu karşılaştırma testi kullanılmıştır.

\section{Bulgular ve Tartışma}

Ayçiçeğinde $\mathrm{N}$ ve $\mathrm{S}$ dozlarının verim ve kalite özelliklerine ilişkin varyans analiz sonuçlarına göre; bütün özelliklerin yıllar arasındaki farklılıkları \%1 düzeyinde önemli bulunmuştur. Diğer taraftan kabuk oranı ve yağ oranı hariç diğer özelliklerin N dozları; yağ oranı hariç diğer özelliklerin $S$ dozları arasındaki farklılıklar \%1 seviyesinde önemlidir. Çiçeklenme zamanı, tohum ve yağ verimi için $\mathrm{N} \times \mathrm{S}$ interaksiyonu; tohum ve yağ verimi için Yll $\times \mathrm{N}$ interaksiyonu; kabuk oranı ve yağ verimi için Yıl $\times$ S interaksiyonunun önemli olduğu tespit edilmiştir (Tablo 2).

Azot ve kükürt uygulamalarına göre bitkilerin çiçeklenme zamanı 2014 yılında 69.2-77.1 gün ve 2015 yllında ise 64.3-72.0 gün arasında değişmiş olup, 2014 yılındaki bitkiler daha geç çiçeklenmiştir. $\mathrm{N} \times \mathrm{S}$ interaksiyonuna göre $\mathrm{N}$ ve $\mathrm{S}$ dozu artışına paralel olarak bitkilerde erkencilik teşvik edilmiş ve çiçeklenme zamanı kontrolde 74.5 gün olan çiçeklenme zamanı en yüksek $\mathrm{N}$ ve $\mathrm{S}$ dozu uygulamasında 66.8 güne gerilemiştir (Tablo 3). Yapılan araştırmalarda lokasyon, çeşit ve kuru veya sulu yetiştirilme durumuna göre ayçiçeğinde çiçeklenme gün sayısı ile ilgili farklı sonuçlar elde edilmiştir. Evci vd. [16] ayçiçeğinde çiçeklenme gün sayısının 54.0-76.0 gün ve Demir [9] ise 60.6-66.3 gün arasında değişim gösterdiğini rapor etmişlerdir. Ancak yapılan araştırmalarda ayçiçeğinde çiçeklenme süresi üzerine ışık yoğunluğu, gün uzunluğu, enlem dereceleri ve sicaklığın etkili olabileceği bildirilmektedir [17]. Azot ve kükürt uygulaması bitkilerde erken çiçeklenmeyi teşvik etmiştir. Azot ve kükürt dozlarının artışı ile erken çiçeklenme sayesinde tohum olgunlaşma döneminin uzamasına ve dolaylı olarak tohum veriminin artışına neden olmuştur. Kaya vd. [18] çiçeklenme süresi ile verim arasında negatif ilişki olduğunu ve erken çiçeklenen çeşitlerin daha verimli olduğunu belirtmişlerdir. 
Tablo 2. Ayçiçeğinde N ve S uygulamalarının verim ve kaliteye etkileri ile ilgili varyans analiz sonuçları

\begin{tabular}{|c|c|c|c|c|c|}
\hline V.K. & S.D. & $\begin{array}{l}\text { Çiçeklenme zamanı } \\
\text { (gün) }^{1}\end{array}$ & $\begin{array}{l}\text { Bitki boyu } \\
\text { (cm) }\end{array}$ & $\begin{array}{l}\text { Tabla çapı } \\
\text { (cm) }\end{array}$ & $\begin{array}{l}1.000 \text { tane ağırlığı } \\
(\mathrm{g})\end{array}$ \\
\hline Yil & 1 & $591.5^{* *}$ & $6934.3^{* *}$ & $606.6^{* *}$ & $747.0^{* *}$ \\
\hline Blok (Yll) & 4 & $13.5^{* *}$ & 42.1 & 1.0 & 10.7 \\
\hline $\operatorname{Azot}(\mathrm{N})$ & 3 & $29.7^{* *}$ & $1387.9^{* *}$ & $66.8^{* *}$ & $140.3^{* *}$ \\
\hline Yll $\times N$ & 3 & 0.01 & 6.7 & 1.5 & 0.43 \\
\hline Hata-1 & 12 & 0.2 & 51.9 & 1.1 & 7.1 \\
\hline Kükürt (S) & 3 & $65.1^{* *}$ & $316.2^{* *}$ & $8.6^{* *}$ & $70.4^{* *}$ \\
\hline Yll $\times S$ & 3 & 0.02 & 1.5 & 0.2 & 0.1 \\
\hline $\mathrm{N} \times \mathrm{S}$ & 9 & $4.3^{* *}$ & 43.5 & 0.8 & 4.6 \\
\hline Yll $\times N \times S$ & 9 & 0.01 & 0.2 & 0.02 & 0.3 \\
\hline Hata-2 & 48 & 0.5 & 31.9 & 2.5 & 5.6 \\
\hline CV (\%) & & 1.1 & 3.9 & 7.1 & 6.1 \\
\hline V.K. & S.D. & $\begin{array}{c}\text { Tohum verimi } \\
\text { (kg/da) }\end{array}$ & $\begin{array}{c}\text { Kabuk oranı } \\
(\%)\end{array}$ & $\begin{array}{l}\text { Yağ oranı } \\
(\%)\end{array}$ & $\begin{array}{c}\text { Yağ verimi } \\
(\%)\end{array}$ \\
\hline Yil & 1 & $314.8^{* *}$ & $384.0^{* *}$ & $9.1^{* *}$ & $9245.3^{* *}$ \\
\hline Blok (Yll) & 4 & 0.6 & 5.8 & 0.1 & 104.4 \\
\hline $\operatorname{Azot}(\mathrm{N})$ & 3 & $104.1^{* *}$ & 0.4 & $3.7^{* *}$ & $4508.9^{* *}$ \\
\hline Yll $\times N$ & 3 & $27.3^{* *}$ & 0.7 & 1.0 & $1250.5^{* *}$ \\
\hline Hata-1 & 12 & 1.7 & 2.0 & 0.5 & 92.9 \\
\hline Kükürt (S) & 3 & $54.6^{* *}$ & $20.9^{* *}$ & $22.1^{* *}$ & $2636.8^{* *}$ \\
\hline Yll $\times S$ & 3 & 1.7 & $10.8^{*}$ & 0.5 & $230.7^{* *}$ \\
\hline $\mathrm{N} \times \mathrm{S}$ & 9 & $7.0^{* *}$ & 2.5 & 1.2 & $226.8^{* *}$ \\
\hline Yll $\times N \times S$ & 9 & 0.7 & 3.7 & 0.7 & 26.7 \\
\hline Hata-2 & 48 & 219.9 & 3.6 & 0.6 & 49.8 \\
\hline CV (\%) & & 5.4 & 6.5 & 1.9 & 6.1 \\
\hline
\end{tabular}

Azot ve kükürt kaynaklı gübrelerin ayçiçeğinde bitki boyuna önemli etkisi olmuştur. 2014 yllında bitkiler $(153.6 \mathrm{~cm}) 2015$ yllına göre $(136.7 \mathrm{~cm})$ daha uzun boylu olduğu tespit edilmiștir. Bu yılda bitkilerin daha uzun boylu olması tohum ekiminden sonra çiçeklenme zamanına kadar (özellikle mayıs ve haziran aylarında) yağışın daha fazla olmasından kaynaklanabilir. Çalıșmada hem $\mathrm{N}$ hem de $\mathrm{S}$ dozu artışı ile birlikte bitki boyu da artmıștır. $\mathrm{N}$ uygulaması bitki boyunu \%12 artırırken, S uygulamasında \%5 artış sağlanmıştır (Tablo 3). Kaya vd. [18] ayçiçeğinde bitki boyunun 105-180 cm arasında değiştiğini bildirmişlerdir. Ayçiçeğinde S dozu artışına paralel olarak bitki boyunun pozitif yönde etkilendiği birçok araştırıcı tarafından da belirtilmiştir $[9,10,19,20]$.

Her iki yıl sonuçlarına göre $\mathrm{N}$ ve $\mathrm{S}$ uygulamasında bitkilerin tabla çapı 14.6-31.2 cm arasında değişim göstermiştir. 2014 yılında ortalama tabla çapı 26.0 $\mathrm{cm}$ ve 2015 yılında $18.1 \mathrm{~cm}$ olarak belirlenmiştir (Tablo 3). 2014 yllında bitkilerin vejetatif döneminde düşen yağışların daha fazla olması bitkilerin boylarını artırarak daha fazla yaprak alanı oluşturmasına bağlı olarak fotosentez etkinliğinin arttığı ve bu sayede bitkilerin daha iri tabla oluşturdukları düşünülmektedir. Azot dozu ortalamalarına göre en geniş tabla çapı $10 \mathrm{~kg} \mathrm{~N} /$ da uygulamasından (25.0 $\mathrm{cm})$ ve en dar ise kontrolden elde edilmiştir. Kükürt uygulamasına göre tabla çapı kontrolden $5 \mathrm{~kg} \mathrm{~S} /$ da'a kadar artmış ve sonraki dozlarda azalmıştır. En yüksek tabla çapı 5 ve $10 \mathrm{~kg} \mathrm{~S} /$ da uygulamasından sırasıyla 23.1 ve $22.4 \mathrm{~cm}$ olarak tespit edilmiştir (Tablo 3). Farklı lokasyonlarda yapılan çalışmalarda ayçiçeğinde tabla çapını Demir [9] 17.2-23.1 cm, Evci vd. [10] 10.0-30.0 cm ve Şahin [21] ise 20.3-28.1 cm arasında değiştiğini rapor etmişlerdir. Çalışmamızda ve diğer çalışmalarda tabla çapı bakımından gözlenen varyasyonlar genetik ve çevresel farklılıklardan ileri gelmektedir. Ayçiçeğinde kükürtlü gübre uygulanması sonucunda kükürdün tabla çapını olumlu yönde etkilediği ve tabla çapını artırdığı çok sayıda araştırıcı tarafından da bildirilmiştir [8, 20].

Ayçiçeğinde tohum verimini belirleyen diğer önemli bir seleksiyon kriteri de 1.000 tane ağırlığıdır. Çalışmada tohumların 1.000 tane ağırlığı 2014 yılında (61.1 g) daha yüksek (2015 yılında 55.6 g) bulunmuştur. $\mathrm{Bu}$ yılda düşen yağış miktarının bitkilerin boyunu ve tabla çapları pozitif yönde etkilemesine bağlı olarak tohum ağırlıklarını da artırdığı düşünülmektedir. Ayçiçeğinde bin tane ağırlığı bakımından farklı lokasyonlarında yürütülen denemelerde Demir [9] 45.3-79.8 g ve Şahin [21] 54.494.6 g arasında değiștiğini bildirmişler ve sonuçlarımız da bu varyasyonlar ile uyumlu bulunmuştur. Azot dozları ortalamasına göre en yüksek 1.000 tane ağırlığ $10 \mathrm{~kg} \mathrm{~N} /$ da uygulamasından elde edilirken, en düșük kontrolde ölçülmüștür. Gül ve Kara [22] ayçiçeğinde N uygulaması ile birlikte 1.000 tane ağırlığının arttığını en yüksek 1.000 tane ağırlığının $15 \mathrm{~kg}$ N/da uygulamasından elde edildiğini rapor etmişlerdir. Diğer taraftan S dozları arttıkça tohumların 1000 tane ağırlıkları kontrole göre \%6.5 oranında artış göstermiştir (Tablo 3). Ayrıca Ishfaq [23] $15 \mathrm{~kg} \mathrm{~S} /$ da uygulamasının 1.000 tane ağırlığını \%15.9 oranında artırdığını rapor etmiştir. Diğer taraftan farklı araştırıcılarda kükürdün 1000 tane ağırlığı üzerine pozitif yönde etkilediği ve önemli ölçüde artırdığını bildirmişlerdir [8, 24]. 
Tablo 3. Ayçiçeğinde N ve S uygulamalarının bazı agronomik özelliklerine ilişkin ortalama değerler

\begin{tabular}{|c|c|c|c|c|c|c|c|c|c|c|c|}
\hline \multirow{3}{*}{ Yil } & \multirow{3}{*}{$\mathbf{N}$} & \multicolumn{5}{|c|}{ Çiçeklenme gün sayısı (gün) } & \multicolumn{5}{|c|}{ Bitki boyu (cm) } \\
\hline & & \multicolumn{5}{|c|}{$\mathbf{S}$} & \multicolumn{5}{|c|}{$\mathbf{S}$} \\
\hline & & $\mathbf{0}$ & 5 & 10 & 15 & Ort. & $\mathbf{0}$ & 5 & 10 & 15 & Ort. \\
\hline \multirow{4}{*}{2014} & 0 & 77.1 & 73.7 & 72.0 & 71.6 & 73.6 & 141.4 & 147.5 & 149.1 & 149.1 & 146.8 \\
\hline & 5 & 73.7 & 72.6 & 72.0 & 71.3 & 72.4 & 144.9 & 147.2 & 151.0 & 155.2 & 149.6 \\
\hline & 10 & 73.3 & 70.9 & 69.9 & 69.9 & 71.0 & 146.0 & 153.7 & 153.7 & 157.9 & 152.8 \\
\hline & 15 & 73.0 & 73.0 & 70.9 & 69.2 & 71.5 & 161.3 & 162.9 & 172.8 & 163.8 & 165.2 \\
\hline \multirow[t]{2}{*}{ Ort. } & & 74.3 & 72.6 & 71.2 & 70.5 & $72.1 A^{1}$ & 148.4 & 152.8 & 156.7 & 156.5 & $153.6 \mathrm{~A}$ \\
\hline & 0 & 72.0 & 68.7 & 67.0 & 66.7 & 68.6 & 126.0 & 131.3 & 132.7 & 132.7 & 130.7 \\
\hline \multirow{3}{*}{2015} & 5 & 68.7 & 67.7 & 67.0 & 66.3 & 67.4 & 129.0 & 131.0 & 134.3 & 138.0 & 133.1 \\
\hline & 10 & 68.3 & 66.0 & 65.0 & 65.0 & 66.1 & 130.0 & 136.7 & 136.7 & 140.3 & 135.9 \\
\hline & 15 & 68.0 & 68.0 & 66.0 & 64.3 & 66.5 & 145.3 & 144.7 & 153.3 & 145.5 & 147.2 \\
\hline \multirow[t]{2}{*}{ Ort. } & & 69.3 & 67.6 & 66.3 & 65.6 & $67.2 \mathrm{~B}$ & 132.6 & 135.9 & 139.3 & 139.1 & 136.7 B \\
\hline & 0 & $74.5 \mathrm{a}$ & $71.2 \mathrm{~b}$ & $69.5 \mathrm{c}-\mathrm{e}$ & $69.1 \mathrm{de}$ & $71.1 \mathrm{a}$ & 133.7 & 139.4 & 140.9 & 140.9 & $138.7 \mathrm{c}$ \\
\hline \multirow{3}{*}{$\mathrm{N} \times \mathrm{S}$} & 5 & $71.2 \mathrm{~b}$ & $70.2 \mathrm{~b}-\mathrm{d}$ & $69.5 \mathrm{c}-\mathrm{e}$ & 68.8 e & $69.9 \mathrm{~b}$ & 137.0 & 139.1 & 142.7 & 146.6 & $141.3 \mathrm{bc}$ \\
\hline & 10 & $70.8 \mathrm{~b}$ & $68.5 \mathrm{ef}$ & $67.5 \mathrm{fg}$ & $67.5 \mathrm{fg}$ & $69.1 \mathrm{c}$ & 138.0 & 145.2 & 145.2 & 149.1 & $144.4 \mathrm{~b}$ \\
\hline & 15 & $70.5 \mathrm{bc}$ & $70.5 \mathrm{bc}$ & $68.5 \mathrm{ef}$ & $66.8 \mathrm{~g}$ & $68.5 \mathrm{~d}$ & 153.3 & 153.8 & 163.1 & 154.7 & $156.2 \mathrm{a}$ \\
\hline \multirow[t]{2}{*}{ Ort. } & & $71.8 \mathrm{a}$ & $70.1 \mathrm{~b}$ & $68.7 \mathrm{c}$ & $68.0 \mathrm{~d}$ & & $140.5 \mathrm{c}$ & $144.4 \mathrm{~b}$ & $148.0 \mathrm{a}$ & $147.8 \mathrm{a}$ & \\
\hline & & \multicolumn{5}{|c|}{ Tabla çapı (cm) } & \multicolumn{5}{|c|}{1.000 tane ağırlığı (g) } \\
\hline \multirow[t]{3}{*}{ Yil } & $\mathbf{N}$ & \multicolumn{5}{|c|}{$\mathrm{S}$} & \multicolumn{5}{|c|}{$\mathbf{S}$} \\
\hline & & $\mathbf{0}$ & 5 & 10 & 15 & Ort. & $\mathbf{0}$ & 5 & 10 & 15 & Ort. \\
\hline & 0 & 21.2 & 24.3 & 23.3 & 22.2 & 22.8 & 57.7 & 58.0 & 59.0 & 59.6 & 58.6 \\
\hline \multirow{3}{*}{2014} & 5 & 23.6 & 24.8 & 24.3 & 24.3 & 24.3 & 58.2 & 58.3 & 61.9 & 62.1 & 60.1 \\
\hline & 10 & 27.4 & 31.2 & 30.4 & 28.3 & 29.3 & 61.2 & 64.5 & 66.1 & 66.2 & 64.5 \\
\hline & 15 & 26.3 & 28.5 & 27.4 & 27.7 & 27.5 & 59.3 & 59.8 & 62.4 & 63.8 & 61.3 \\
\hline \multirow[t]{2}{*}{ Ort. } & & 24.6 & 27.2 & 26.4 & 25.6 & $26.0 \mathrm{~A}$ & 59.1 & 60.2 & 62.4 & 62.9 & $61.1 \mathrm{~A}$ \\
\hline & 0 & 14.6 & 16.9 & 16.2 & 15.3 & 15.8 & 52.5 & 52.7 & 53.6 & 54.2 & 53.3 \\
\hline \multirow{3}{*}{2015} & 5 & 16.4 & 17.2 & 16.9 & 16.9 & 16.9 & 52.9 & 53.0 & 56.3 & 56.4 & 54.7 \\
\hline & 10 & 19.2 & 22.0 & 21.4 & 19.9 & 20.6 & 55.7 & 58.6 & 60.1 & 60.2 & 58.7 \\
\hline & 15 & 18.4 & 20.0 & 19.2 & 19.4 & 19.3 & 53.9 & 54.3 & 56.8 & 58.0 & 55.8 \\
\hline \multirow[t]{2}{*}{ Ort. } & & 17.2 & 19.0 & 18.4 & 17.9 & 18.1 B & 53.8 & 54.7 & 56.7 & 57.2 & 55.6 B \\
\hline & 0 & 17.9 & 20.6 & 19.8 & 18.8 & $19.3 \mathrm{~d}$ & 55.1 & 55.4 & 56.3 & 56.9 & $55.9 \mathrm{c}$ \\
\hline \multirow{3}{*}{$\mathrm{N} \times \mathrm{S}$} & 5 & 20.0 & 21.0 & 20.6 & 20.6 & $20.6 \mathrm{c}$ & 55.6 & 55.7 & 59.1 & 59.3 & $57.4 \mathrm{bc}$ \\
\hline & 10 & 23.3 & 26.6 & 25.9 & 24.1 & 25.0 a & 58.5 & 61.6 & 63.1 & 63.2 & $61.6 \mathrm{a}$ \\
\hline & 15 & 22.4 & 24.3 & 23.3 & 23.6 & $23.4 \mathrm{~b}$ & 56.6 & 57.1 & 59.6 & 60.9 & $58.5 \mathrm{~b}$ \\
\hline Ort. & & $20.9 c$ & $23.1 \mathrm{a}$ & $22.4 \mathrm{ab}$ & $21.8 \mathrm{bc}$ & & $56.4 \mathrm{c}$ & $57.4 \mathrm{bc}$ & $59.5 \mathrm{~b}$ & $60.1 \mathrm{a}$ & \\
\hline
\end{tabular}

1: Aynı harflere sahip ortalamalar arasında istatistiksel farklılık bulunmamaktadır.

Ayçiçeğinde tohum veriminin artırılması en önemli yetiştiricilik hedeflerinden birisidir. Her iki yll sonuçlarına göre tohum verimi 2014 yllında 235.4$348.6 \mathrm{~kg} / \mathrm{da}\left(\mathrm{N}_{0} \mathrm{~S}_{0}-\mathrm{N}_{5} \mathrm{~S}_{5}\right)$ ve 2015 yılında $174.4-327.4$ $\mathrm{kg} / \mathrm{da}\left(\mathrm{N}_{0} \mathrm{~S}_{0}-\mathrm{N}_{10} \mathrm{~S}_{5}\right)$ arasında değișmiștir. Ylllara göre 2014 yllında en yüksek tane verimi $(300.4 \mathrm{kd} / \mathrm{da})$ elde edilmiștir (Tablo 4). Bu farklılık 2014 yılı yağış miktarının yüksek olmasından kaynaklanabilir. Çalışmada incelenen bitki boyu, tabla çapı, 1.000 tane ağırlığı gibi verim bileşenlerinin 2014 yllında daha yüksek olması tohum verimine olumlu katkı sağlamıș olabilir. Nitekim ayçiçeğinde tohum veriminin aynı lokasyonda ylllara göre farklılık gösterebileceği, genetik $\times$ çevre interaksiyonunun yüksek olduğu ve tohum veriminin kalıtımında birçok eklemeli etkili genlerin rol aldığı ve orta düzeyde kalıtım derecesine tahminlendiği rapor edilmektedir [25]. Azot dozu ortalamalarına göre kontrol parsellerinde 231.9 $\mathrm{kg} / \mathrm{da}$ olan tohum verimi $10 \mathrm{~kg} \mathrm{~N} /$ da'a kadar $\% 31.3$ oranında artış göstererek $304.4 \mathrm{~kg} / \mathrm{da}$ 'a ulaşmıștır. Daha sonraki doz artışı ile birlikte gerileyerek $15 \mathrm{~kg}$ $\mathrm{N} /$ da uygulamasında $286.7 \mathrm{~kg} /$ da'a düșmüștür (Tablo 4). Yapılan araștırmalarda tohum verimi üzerine $\mathrm{N}$ uygulamalarının önemli etkisinin olduğu ve $\mathrm{N}$ dozu arttıkça tohum veriminin de arttığı bildirilmektedir.
Gül ve Kara [22] ayçiçeğinde en yüksek tohum veriminin $15 \mathrm{~kg} \mathrm{~N} / \mathrm{da}$, Namwar vd. [26] $12 \mathrm{~kg} \mathrm{~N} / \mathrm{da}$ ve Evci vd. [27] 5-10 kg N/da uygulamasindan elde edildiğini rapor etmișlerdir. Sonuçlarımız Namwar vd. [26] ve Evci vd. [27]'nin sonuçları ile benzerlik göstermektedir. Çalışmada $\mathrm{S}$ dozu ortalamalarına göre en yüksek tohum verimi $5 \mathrm{~kg} \mathrm{~S} / \mathrm{da}$ uygulamasından $(302.8 \mathrm{~kg} / \mathrm{da})$ ve en düşük kontrol parsellerinden $(248.4 \mathrm{~kg} / \mathrm{da})$ elde edilmiştir (Tablo 4). Ayçiçeğinde azot ve kükürdün tohum verimini artırdığı birçok araștırıcı tarafından rapor edilmiștir $[8,19,24]$. Ancak yüksek miktarda S uygulamasının ayçiçeğinde toksisiteye neden olduğu rapor edilmektedir. Ayçiçeğinde $8 \mathrm{~kg} \quad \mathrm{~S} / \mathrm{da}$ dozunun üzerinde yapılan $S$ gübrelemesinin $N, P$ ve $K$ gibi besin elementlerinin alımını engellediği ve tohum verimini önemli oranda düşürdüğü bildirilmektedir [28]. Nitekim çalışmamızda $5 \mathrm{~kg} \quad \mathrm{~S} / \mathrm{da}$ uygulamasından sonra tohum verimi azalmıștır. Diğer taraftan ayçiçeğinde $8 \mathrm{~kg} \mathrm{~S} / \mathrm{da}$ ve $14 \mathrm{~kg} \mathrm{~N} / \mathrm{da}$ uygulaması ile bitkilerin en yüksek yaprak alanına ulaştığı ve bu gübre kombinasyonunda net asimilasyon oranının en üst seviyeye çıktığı ve dolayısıyla en yüksek tohum veriminin bu uygulamalardan elde edildiği rapor edilmektedir [29]. 
Tablo 4. Ayçiçeğinde N ve S uygulamalarının tohum verimi ve kalite özelliklerine ilişkin ortalama değerler

\begin{tabular}{|c|c|c|c|c|c|c|c|c|c|c|c|}
\hline \multirow{3}{*}{ Yil } & \multirow{3}{*}{$\mathbf{N}$} & \multicolumn{5}{|c|}{ Tohum verimi $(\mathrm{kg} / \mathrm{da})$} & \multicolumn{5}{|c|}{ Kabuk oranı (\%) } \\
\hline & & \multicolumn{5}{|c|}{$\mathbf{S}$} & \multicolumn{5}{|c|}{$\mathbf{S}$} \\
\hline & & $\mathbf{0}$ & 5 & 10 & 15 & Ort. & $\mathbf{0}$ & 5 & 10 & 15 & Ort. \\
\hline & 0 & 235.4 & 300.9 & 252.0 & 279.9 & $267.1 b^{1}$ & 27.4 & 28.0 & 26.0 & 28.0 & 27.4 \\
\hline \multirow{3}{*}{2014} & 5 & 271.4 & 348.6 & 296.1 & 334.3 & $312.6 \mathrm{a}$ & 25.2 & 29.0 & 26.3 & 29.0 & 27.4 \\
\hline & 10 & 303.7 & 319.7 & 310.2 & 304.6 & $309.6 \mathrm{a}$ & 27.1 & 28.6 & 26.9 & 27.0 & 27.4 \\
\hline & 15 & 293.3 & 345.4 & 319.1 & 291.6 & $312.4 \mathrm{a}$ & 28.5 & 26.9 & 27.3 & 27.3 & 27.5 \\
\hline \multirow[t]{2}{*}{ Ort. } & & 276.0 & 328.7 & 294.4 & 302.6 & $300.4 \mathrm{~A}$ & $27.1 \mathrm{~d}$ & $28.1 \mathrm{~cd}$ & $26.6 \mathrm{~d}$ & $27.8 \mathrm{~d}$ & 27.4 B \\
\hline & 0 & 174.4 & 223.3 & 185.7 & 203.6 & $196.8 \mathrm{~d}$ & 33.9 & 30.6 & 30.5 & 31.7 & 31.7 \\
\hline \multirow{3}{*}{2015} & 5 & 191.4 & 269.5 & 217.2 & 241.2 & $229.8 \mathrm{c}$ & 33.6 & 33.1 & 29.0 & 30.8 & 31.6 \\
\hline & 10 & 282.4 & 327.4 & 313.6 & 273.4 & $299.2 \mathrm{a}$ & 32.3 & 32.2 & 28.7 & 31.2 & 31.1 \\
\hline & 15 & 235.0 & 287.8 & 283.2 & 237.8 & $261.0 \mathrm{~b}$ & 31.9 & 31.8 & 29.7 & 31.5 & 31.2 \\
\hline \multirow[t]{2}{*}{ Ort. } & & 220.8 & 277.0 & 249.9 & 239.0 & 246.7 B & $32.9 \mathrm{a}$ & $31.9 \mathrm{ab}$ & $29.5 \mathrm{~b}-\mathrm{d}$ & $31.3 \mathrm{a}-\mathrm{c}$ & 31.4 A \\
\hline & 0 & $204.9 \mathrm{~h}$ & $262.1 \mathrm{de}$ & 218.9 gh & $241.8 \mathrm{e}-\mathrm{g}$ & $231.9 d$ & 30.7 & 29.3 & 28.3 & 29.9 & 29.5 \\
\hline \multirow{3}{*}{$\mathrm{N} \times \mathrm{S}$} & 5 & $231.4 \mathrm{fg}$ & $309.1 \mathrm{a}-\mathrm{c}$ & 256.7 ef & $287.8 \mathrm{~cd}$ & $271.2 \mathrm{c}$ & 29.4 & 31.1 & 27.7 & 29.9 & 29.5 \\
\hline & 10 & 293.1 bc & $323.6 \mathrm{a}$ & 311.9 a-c & $289.0 \mathrm{~cd}$ & $304.4 \mathrm{a}$ & 29.7 & 30.4 & 27.8 & 29.1 & 29.3 \\
\hline & 15 & $264.2 \mathrm{de}$ & $316.6 \mathrm{ab}$ & $301.2 \mathrm{a}-\mathrm{c}$ & $264.7 \mathrm{de}$ & $286.7 b$ & 30.2 & 29.4 & 28.5 & 29.4 & 29.4 \\
\hline Ort. & & $248.4 \mathrm{c}$ & $302.8 \mathrm{a}$ & $272.1 \mathrm{~b}$ & $270.8 \mathrm{~b}$ & & $30.0 \mathrm{a}$ & $30.0 \mathrm{a}$ & $28.1 \mathrm{~b}$ & $29.6 \mathrm{a}$ & \\
\hline
\end{tabular}

\begin{tabular}{|c|c|c|c|c|c|c|c|c|c|c|c|}
\hline \multirow{3}{*}{ Yil } & \multirow{3}{*}{$\mathbf{N}$} & \multicolumn{5}{|c|}{ Yağ oranı (\%) } & \multicolumn{5}{|c|}{ Yağ verimi $(\mathrm{kg} / \mathrm{da})$} \\
\hline & & \multicolumn{5}{|c|}{$\mathbf{S}$} & \multicolumn{5}{|c|}{$\mathbf{S}$} \\
\hline & & $\mathbf{0}$ & 5 & 10 & 15 & Ort. & $\mathbf{0}$ & 5 & 10 & 15 & Ort. \\
\hline \multirow{4}{*}{2014} & 0 & 41.0 & 42.4 & 42.9 & 43.5 & 42.5 & 102.5 & 125.2 & 103.2 & 117.9 & $112.2 \mathrm{~b}$ \\
\hline & 5 & 41.7 & 42.8 & 43.1 & 42.1 & 42.4 & 114.9 & 144.9 & 122.7 & 140.7 & $130.8 \mathrm{a}$ \\
\hline & 10 & 41.1 & 42.6 & 43.8 & 43.9 & 42.9 & 127.1 & 137.9 & 125.1 & 126.4 & $129.1 \mathrm{a}$ \\
\hline & 15 & 43.0 & 43.4 & 43.7 & 44.5 & 43.7 & 125.3 & 146.6 & 134.7 & 136.9 & $135.9 \mathrm{a}$ \\
\hline \multirow[t]{2}{*}{ Ort. } & & 41.7 & 42.8 & 43.4 & 43.5 & $42.8 \mathrm{~A}$ & $117.5 \mathrm{c}$ & 138.7 a & $121.4 \mathrm{bc}$ & $130.5 \mathrm{ab}$ & $127.0 \mathrm{~A}$ \\
\hline & 0 & 41.3 & 42.9 & 44.2 & 44.4 & 43.2 & 72.1 & 98.7 & 79.7 & 90.3 & $85.2 \mathrm{c}$ \\
\hline \multirow{3}{*}{2015} & 5 & 41.1 & 43.6 & 44.8 & 43.9 & 43.4 & 78.5 & 120.7 & 74.6 & 105.9 & $94.9 \mathrm{c}$ \\
\hline & 10 & 42.2 & 43.8 & 44.0 & 44.3 & 43.6 & 119.1 & 144.1 & 137.3 & 121.1 & $130.4 \mathrm{a}$ \\
\hline & 15 & 43.0 & 43.7 & 43.8 & 44.2 & 43.7 & 101.0 & 126.1 & 123.7 & 105.0 & $114.0 \mathrm{~b}$ \\
\hline \multirow[t]{2}{*}{ Ort. } & & 41.9 & 43.5 & 44.2 & 44.2 & 43.5 B & $92.7 \mathrm{e}$ & $122.4 \mathrm{bc}$ & $103.8 \mathrm{de}$ & $105.6 \mathrm{~d}$ & 106.1 B \\
\hline & 0 & 41.2 & 42.7 & 43.6 & 44.0 & $42.8 \mathrm{~b}$ & $87.3 \mathrm{~g}$ & $112.0 \mathrm{de}$ & $91.5 \mathrm{~g}$ & 104.1 ef & $98.7 \mathrm{c}$ \\
\hline \multirow{3}{*}{$\mathrm{N} \times \mathrm{S}$} & 5 & 41.4 & 43.2 & 44.0 & 43.0 & $42.9 \mathrm{~b}$ & $96.7 \mathrm{fg}$ & $132.8 \mathrm{a}-\mathrm{c}$ & $98.7 \mathrm{fg}$ & $123.3 \mathrm{~cd}$ & $112.9 \mathrm{~b}$ \\
\hline & 10 & 41.7 & 43.2 & 43.9 & 44.1 & $43.2 \mathrm{~b}$ & $123.1 \mathrm{~cd}$ & $141.0 \mathrm{a}$ & $131.2 \mathrm{a}-\mathrm{c}$ & $123.8 \mathrm{~b}-\mathrm{d}$ & $129.8 \mathrm{a}$ \\
\hline & 15 & 43.0 & 43.6 & 43.8 & 44.4 & 43.7 a & $113.2 \mathrm{de}$ & $136.4 \mathrm{ab}$ & $129.2 \mathrm{a}-\mathrm{c}$ & $121.0 \mathrm{~cd}$ & $124.9 \mathrm{a}$ \\
\hline Ort. & & $41.8 \mathrm{c}$ & $43.2 \mathrm{~b}$ & $43.8 \mathrm{a}$ & $43.9 \mathrm{a}$ & & $105.1 \mathrm{c}$ & $130.5 \mathrm{a}$ & $112.6 \mathrm{~b}$ & $118.0 \mathrm{~b}$ & \\
\hline
\end{tabular}

1: Aynı harflere sahip ortalamalar arasında istatistiksel farklılık bulunmamaktadır.

Ayçiçeği tohumlarında kabuk oranının azaltılması önemli ıslah amaçlarından biridir. Geliştirilen çeşitlerde kabuk oranının \% 25'in altına düşürülmesi hedeflenmektedir. Çalışmada tohumların kabuk oranları yıllara göre farklılık göstermiş ve 2015 yılında kabuk oranı daha yüksek (\%31.4) bulunmuştur (Tablo 4). İklim verileri incelendiğinde bu yılda düșen yağıș miktarının bir önceki ylla göre daha az olması nedeniyle tohum verimi ve verim bileşenlerinin düşük olması tohumlarda kabuk oranını artırdığı düşünülmektedir. Uygulamalarda sadece S dozları arasındaki farklılıklar önemli bulunmuş $(\mathrm{p}<0.01)$ ve en düşük kabuk oranı $10 \mathrm{~kg}$ $\mathrm{S} /$ da uygulamasından elde edilmiştir. Ayçiçeği tohumlarında yağ oranı artışı 1000 tane ağırlı̆̆ 55 g'a ulaşana kadar devam ettiği, tane ağırlığı 55 g'ın üzerine çıktıkça tohumların yağ içeriğinin azaldığı ve kabuk oranının ise artış gösterdiği bildirilmektedir [16]. Çalışmamızda S uygulamasının tohumlarda yağ sentezini teşvik ettiği ve dolayısıyla kabuk oranını azalttığı düşünülmektedir. Nitekim ayçiçeğinde kabuk ve yağ oranı arasında negatif bir korelasyon olduğunu rapor edilmektedir [3].
Yağlık ayçiçeği tohumlarının ekonomik değerinin \%80'inden daha fazlasını ham yağ olușturmaktadır. Çalışmamızda $\mathrm{N}$ ve $\mathrm{S}$ uygulamaları tohumların yağ içeriği üzerine önemli etki göstermiştir. Yıllara göre ortalama yağ oranı 2014 yılında \%42.8 iken, 2015 yılında \%43.5 oranında tespit edilmiştir. Denemenin 2. yılında bitkilerin tohum veriminin düşük olmasından dolayı yağ içeriğinin daha yüksek çıktığı düşünülmektedir. Zira ayçiçeğinde yağ oranı ve tohum verimi arasında negatif ilişki olduğu rapor edilmektedir [18]. $\mathrm{N}$ ve S uygulama dozları arttıkça tohumların yağ içeriği artmış olup, kontrole göre en yüksek dozda $\mathrm{N}$ uygulamasında $\% 2.1$ ve $\mathrm{S}$ uygulamasında \%5.0 oranında artış tespit edilmiştir (Tablo 4). S uygulaması ile ayçiçeğinde yağ içeriğinin \%18 oranında arttığını bildirilmektedir [8]. Bazı araştırmalarda azotun tohumun protein içeriğini artırıcı etkisinden dolayı yağ içeriğine olumsuz etkisi olduğu tespit edilse de [30], S ve $\mathrm{N}$ aynı anda uygulandığında yağ içeriğinin önemli oranda arttığı rapor edilmektedir [10]. 
Ayçiçeğinde yüksek tohum verimliliği kadar yağ verimliliğinin de yüksek olması arzulanmaktadır. Yıllara göre yă verimi 2014 yllında 102.5-146.6 $\mathrm{kg} / \mathrm{da}\left(\mathrm{N}_{0} \mathrm{~S}_{0}-\mathrm{N}_{15} \mathrm{~S}_{5}\right)$ ve 2015 yllinda $87.3-141.0 \mathrm{~kg} / \mathrm{da}$ $\left(\mathrm{N}_{0} \mathrm{~S}_{0}-\mathrm{N}_{10} \mathrm{~S}_{5}\right)$ arasında değişmiştir. Yıllara göre 2014 yılında en yüksek yağ verimi $(127.0 \mathrm{~kg} / \mathrm{da})$ elde edilmiştir (Tablo 4). Yağış miktarının 2014 yılında daha yüksek olması tohum verimini artırmış ve dolaylı olarak yağ verimi de artış sağlamıștır. Ayçiçeğinde diğer agronomik ve kalite özelliklerinde olduğu gibi yağ veriminin kalıtımında da eklemeli etkili genlerin rol aldı̆̆ ve bundan dolayı yağ veriminin çeşitlerin genetik yapısı, bunların yağ oranı ve tohum verimleri ile yetiştirme teknikleri ve ekolojik faktörlere bağlı olarak değiştiği bir çok araştırıcı tarafından bildirilmiştir $[9,21]$. Azot dozlarına göre kontrol parsellerinde ortalama 98.7 $\mathrm{kg} / \mathrm{da}$ olan yağ verimi $10 \mathrm{~kg} \mathrm{~N} / \mathrm{da}$ 'a kadar \%31.5 oranında artış göstererek $129.8 \mathrm{~kg} / \mathrm{da}$ a ulaşmıştır. Daha sonraki doz artışı ile birlikte $15 \mathrm{~kg}$ N/da uygulamasında $124.9 \mathrm{~kg} /$ da'a düșmüş, ancak bu azalma istatistiksel olarak önemli bulunmamıştır (Tablo 4). Ayçiçeğinde yağ verimi üzerine $\mathrm{N}$ uygulamalarının olumlu bir etkisi olduğu rapor edilmiş ve yüksek yağ verimi için en uygun azot uygulamasını Gül ve Kara [22] 15 kg N/da, Namwar vd. [26] $12 \mathrm{~kg} \mathrm{~N} / \mathrm{da}$ ve Evci vd. [27] 5-10 kg N/da olduğunu önermişlerdir. Sonuçlarımız bu bulgular ile uyumludur. Kükürt uygulamalarına göre en yüksek yağ verimi $5 \mathrm{~kg} \mathrm{~S} /$ da uygulamasından $(130.5 \mathrm{~kg} / \mathrm{da})$ ve en düşük kontrolden $(105.1 \mathrm{~kg} / \mathrm{da})$ elde edilmiștir (Tablo 4). Azot ve kükürt gübrelerinin birlikte uygulanması tohum verimini artırdığı gibi yağ oranını da artırmış ve dolayısıyla yağ verimi üzerine önemli bir etkisi olmuştur. Ayçiçeğinde azot ve kükürdün yağ verimini belirli bir doza kadar artırdığı, daha yüksek dozlarda toksisiteye neden olduğu rapor edilmektedir $[8,19,28]$.

Azot ve kükürt uygulamalarının yağ asitleri kompozisyonu üzerine etkisi incelendiğinde 2014 ve 2015 ylllarında palmitik asit oranı sırasıly \%4.226.26 ve $\% 4.44-6.24$, stearik asit oranı $\% 1.83-2.64$ ve $\% 1.76-2.80$, oleik asit oranı \%83.01-91.70 ve $\% 86.42-91.09$, linoleik asit oranı ise $\% 1.37-7.25$ ve \%1.67-6.89 arasında değişim göstermiştir (Tablo 5). Çalışmada yılların, gübreler ve dozlarının yağ asitleri üzerine net bir etkisi gözükmemekle birlikte artan N ve S dozlarına karşı oleik asit oranında azalmanın ve linoleik asit oranında bir artışın olduğu görülmektedir. Bazı çalışmalarda $N$ ve $S$ gübrelemesinin ayçiçeğinde oleik asit oranını azalttığı rapor edilmesine rağmen [29, 31], bazılarında etkisinin olmadığı bildirilmektedir [32].

\section{Sonuç}

Sonuç olarak; azot ve kükürt uygulamaları yağlık hibrit ayçiçeğinde verim ve kaliteyi artırmıștır. Isparta koşullarında yağlık ayçiçeği yetiştiriciliğinde daha yüksek verim ve kalite $10 \mathrm{~kg} \mathrm{~N} / \mathrm{da}$ ile $5 \mathrm{~kg} \mathrm{~S} / \mathrm{da}$ kullanılması önerilebilir. Özellikle $S$ içerikli gübre kullanımının teşvik edilmesi ve bu konuda gerekli desteklerin sağlanması bitkisel yağ açı̆̆ının kapatılması, yağ kalitesinin iyileştirilmesi ve ayçiçeği tarımının geliştirilmesine önemli katkılar sağlayacaktır.

Tablo 5. Ayçiçeğinde N ve S uygulamalarının yağ asitleri kompozisyonu (\%) üzerine etkileri

\begin{tabular}{lcccccccc}
\hline Dozlar & \multicolumn{2}{c}{ Palmitik asit (C $\mathbf{1 6 : 0}$ ) } & \multicolumn{2}{c}{ Stearik asit $\left(\mathbf{C}_{\mathbf{1 8}: \mathbf{0}}\right)$} & \multicolumn{2}{c}{ Oleik asit (C18:1) } & \multicolumn{2}{c}{ Linoleik asit (C18:2) } \\
\cline { 2 - 10 } & $\mathbf{2 0 1 4}$ & $\mathbf{2 0 1 5}$ & $\mathbf{2 0 1 4}$ & $\mathbf{2 0 1 5}$ & $\mathbf{2 0 1 4}$ & $\mathbf{2 0 1 5}$ & $\mathbf{2 0 1 4}$ & $\mathbf{2 0 1 5}$ \\
\hline $\mathrm{A}_{0} \mathrm{~S}_{0}$ & 4.62 & 4.90 & 2.25 & 2.39 & 91.53 & 91.01 & 1.58 & 1.67 \\
$\mathrm{~A}_{0} \mathrm{~S}_{5}$ & 6.26 & 6.01 & 1.83 & 1.76 & 89.03 & 89.18 & 2.85 & 3.02 \\
$\mathrm{~A}_{0} \mathrm{~S}_{10}$ & 4.22 & 4.47 & 2.64 & 2.80 & 90.09 & 89.78 & 3.04 & 2.92 \\
$\mathrm{~A}_{0} \mathrm{~S}_{15}$ & 5.81 & 5.58 & 1.90 & 1.82 & 89.22 & 89.35 & 3.04 & 3.22 \\
$\mathrm{~A}_{5} \mathrm{~S}_{0}$ & 4.91 & 4.90 & 2.33 & 2.24 & 91.38 & 91.09 & 1.36 & 1.74 \\
$\mathrm{~A}_{5} \mathrm{~S}_{5}$ & 5.49 & 5.27 & 1.82 & 1.93 & 90.97 & 90.97 & 1.70 & 1.80 \\
$\mathrm{~A}_{5} \mathrm{~S}_{10}$ & 5.22 & 5.14 & 2.25 & 2.20 & 86.41 & 88.98 & 6.09 & 3.66 \\
$\mathrm{~A}_{5} \mathrm{~S}_{15}$ & 5.35 & 5.53 & 2.29 & 2.39 & 88.90 & 86.21 & 3.45 & 5.85 \\
$\mathrm{~A}_{10} \mathrm{~S}_{0}$ & 4.90 & 5.19 & 1.97 & 2.09 & 91.70 & 90.19 & 1.41 & 2.49 \\
$\mathrm{~A}_{10} \mathrm{~S}_{5}$ & 4.63 & 4.44 & 2.47 & 2.37 & 86.74 & 87.26 & 6.14 & 5.89 \\
$\mathrm{~A}_{10} \mathrm{~S}_{10}$ & 5.89 & 6.24 & 2.50 & 2.65 & 86.23 & 85.41 & 5.35 & 5.67 \\
$\mathrm{~A}_{10} \mathrm{~S}_{15}$ & 5.38 & 5.16 & 2.18 & 2.09 & 85.06 & 86.26 & 7.37 & 6.45 \\
$\mathrm{~A}_{15} \mathrm{~S}_{0}$ & 5.27 & 5.59 & 2.50 & 2.65 & 88.92 & 88.25 & 3.29 & 3.49 \\
$\mathrm{~A}_{15} \mathrm{~S}_{5}$ & 5.75 & 5.52 & 2.51 & 2.41 & 90.35 & 88.59 & 1.37 & 3.45 \\
$\mathrm{~A}_{15} \mathrm{~S}_{10}$ & 4.44 & 4.71 & 2.59 & 2.49 & 88.58 & 88.15 & 4.37 & 4.63 \\
$\mathrm{~A}_{15} \mathrm{~S}_{15}$ & 5.28 & 6.07 & 2.44 & 2.59 & 83.01 & 86.42 & 7.25 & 6.89 \\
\hline
\end{tabular}




\section{Kaynakça}

[1] Anonim, 2020a. http://www.fao.org/faostat/ en/\#data/QC (Erișim Tarihi: 10.01.2020).

[2] Anonim, 2020b. http://www.bysd.org.tr/Dis TicaretRakamlari/(Erişim Tarihi: 10.01.2020).

[3] Gültekin, S. 2018. Isparta Koşullarında Bazı Oleik ve Linoleik Asit İçeren Yağlı Hibrit Ayçiçeği (Helianthus annuus L.) Çeșitlerinin Verim ve Kalite Özelliklerinin Belirlenmesi. Süleyman Demirel Üniversitesi, Fen Bilimleri Enstitüsü, Yüksek Lisans Tezi, 68 s, Isparta.

[4] Habib, H., Mehdi, S.S., Rashid A., Anjum, M.A. 2006. Genetic Association and Path Analysis for Seed Yield in Sunflower. Pakistan Journal of Agricultural Sciences, 43,136-139.

[5] Cakmak, I. 2002. Plant Nutrition Research Priorities to Meet Human Needs for Food in Sustainable Ways. Plant Soil. 247,3-24.

[6] Gudade, B.A., Thakur, M.R., Ulemale, R.B., Imade, S.R., Bodhade, M.S. 2009. Nutrient Uptake, Soil Nutrient Status and Quality of New Sunflower Varieties as Influenced by Fertilizer Levels. Journal of Soils and Crops, 19 (2), 355-359.

[7] Marschner, H. 1995. Mineral Nutrition of Higher Plants. Academic Pres, London Sed. Ed. p. 255264.

[8] Hassan, F., Hakim, S.A., Manaf, A., Qadir, G., Ahmad, S. 2007. Response of Sunflower (Helianthus annuus L.) to Sulphur and Seasonal Variations. International Journal of Agriculture and Biology, 9(3),499-503.

[9] Demir, İ. 2009. Azot ve Kükürdün Ayçiçeğinde (Helianthus annuus L.) Verim ve Verim öğeleri ile Bazı Kalite Özellikleri Üzerine Etkisi. Ankara Üniversitesi, Fen Bilimleri Enstitüsü, Doktora Tezi, 113 s, Ankara.

[10] Poonia, K.L. 2000. Effect of Planting Geometry, Nitrogen and Sulfur on Growth and Yield of Sunflower (Helianthus annuus L.). Journal of EcoPhysiology, 3, 59-71.

[11] Najar, G.R., Singh, S.R., Akthar, F. Hakeem, S.A. 2011. Influence of Sulphur levEls on Yield, Uptake and Quality of Soyabean (Glycine max) under Temperate Conditions of Kashmir Valley. Indian Journal of Agricultural Sciences, 81(4), 340-343.

[12] Rowell, D.L. 1996. Soil Science: Methods and Applications. Longman. London.

[13] Anonim, 2020c. Meteoroloji Genel Müdürlüğü.

[14] AOAC, 2005. Official method of Analysis. 18 Edition, Association of Officiating Analytical Chemists, Washington DC.

[15] SAS Institute. 1999. INC SAS/STAT User's Guide Release7.0, Cary, NC, USA.
[16] Evci, G., Pekcan. V., Yılmaz M.İ., Kaya, Y., 2011. Ayçiçeğinde (Helianthus annuus L.) Yağ kalitesi ve verim öğeleri arasındaki ilişkilerin belirlenmesi. Türkiye IX. Tarla Bitkileri Kongresi, 12-15 Eylül, Bursa, 2,815-820.

[17] Connor, D.J., Hall, A.J. 1997. Sunflower Physiology. A.A.Schneiter (ed.) Sunflower Technology and Production. ASA, SCSA Monograph. No: 35, Madison, WI. 113-182.

[18] Kaya, Y., Evci, G., Durak, S., Pekcan, V. ve Gücer, T. 2006 Farklı Çevre Koşullarında Ayçiçeğinde (Helianthus annuus L.) Tane Verimi ve Diğer Verim Öğeleri Arasında İlişkilerin Belirlenmesi. Trakya University Journal of Natural Sciences, $7(1), 37-44$.

[19] Bhagat, G.J., Abdul, H., Bonde, S.P., Giri, M.D., Mohammed, S. 2003. Effect of Irrigation and Sulphur Levels on Growth and Yield Attributes of Rabi Sunflower (Helianthus annuus L.). Research on Crops, 4(1), 56-59.

[20] Ramu, Y.R., Reddy, P.M. 2003. Growth and Yield of Sunflower as Influenced by Nitrogen and Sulphur Nutrition. Indian Journal of Dryland Agricultural Research and Development, 18(2), 192-195.

[21] Şahin, T. 2015. Tokat-Erbaa Şartlarında Bazı Ayçiçeği (Helianthus annuus L.) Çeşitlerinin Performanslarının Belirlenmesi. Gaziosmanpaşa Üniversitesi, Fen Bilimleri Enstitüsü, Yüksek Lisans Tezi, 65s, Tokat.

[22] Gül, V., Kara, K. 2015. Effects of Different Nitrogen Doses on Yield and Quality Traits of Common Sunflower (Helianthus annuus L.). Turkish Journal of Field Crops, 20(2), 159-165.

[23] Ishfaq, M. 2010. Productivity of Sunflower Hybrids as Influenced by Sulphur-Nitrogen Nutrition and Varying Plant Population. Faculty of Agriculture, University of Agriculture, PhD Thesis, 218 p, Pakistan.

[24] Khan, J.M., Khan, H.M., Khattak, A.R. Jan, T.M. 2006. Response of Maize to diffErent Levels of Sulphur. Communications in Soil Science and Plant Analysis, 37(1), 41-51.

[25] Khan, H., Rehman, U.H., Bakht, J., Khan, A.S., Hussain, I., Khan, A., Ali, S. 2013. Genotype $\times$ Environment Interaction and Heritability Estimates for Some Agronomic Characters in Sunflower. The Journal of Animal \& Plant Sciences, 23(4), 1177-1184.

[26] Namvar, A., Khandan, T. Shojaei, M. 2012. Effects of Bio and Chemical Nitrogen Fertilizer on Grain and Oil Yield of Sunflower (Helianthus annuus L.) under Different Rates of Plant Density. Annals of Biology Research, 3(2), 1125-1131.

[27] Evci G., Kaya, Y., Pekcan, V., Durak, S., Kahraman, T. 2006. The Determination of the Effect of 
Cover Crop Before Sunflower Production on Seed Yield, the Application of Nitrogen Rate and Water Content in the Soil in Trakya Region. Trakya University Journal of Natural Science, 7(1), 71-75.

[28] Shamima N., Imamul Huq, S.M. 2002. Effect of Sulphur Fertilizer on Yield and Nutrient Uptake of Sunflower Crop in an Albaquept Soil. Pakistan Journal of Biological Sciences, 5, 533-536.

[29] Iqbal, A. 2008. Production Potential of Autumn Planted Sunflower (Helianthus annuus L). Department of Agronomy, University of Agriculture, PhD Thesis, Pakistan.
[30] Scheiner, J.D., Guterrez-Boem, F.H., Lavado R.S. 2002. Sunflower Nitrogen Requirement and 15 $\mathrm{N}$ Fertilizer Recovery in Western Pampas, Argentina. European Journal of Agronomy, 17, 73-79.

[31] Misra, S.K., Sing, R.N., Tiwari, V.N., Tiwari K.H. 2002. Effect of Sulphur Fertilizer on Quality Characteristics of Mustard Seed in Five Cultivars. Journal of the Indian Society of Soil Science, 50(1), 141-143.

[32] Manaf, A., Hassan, F. 2006. Effects of Sulphur on Fatty Acid Accumulation in Brassica Cultivars. International Journal of Agriculture \& Biology, 5 , 588-592. 